\title{
Nitrate assimilation pathway in higher plants: critical role in nitrogen signalling and utilization
}

\author{
Ahmad Ali \\ Department of Life Sciences, University of Mumbai, Vidyanagari, Santacruz (East), Mumbai 400 098, India \\ *Email: ahmaddali@mu.ac.in
}

ARTICLE HISTORY

Received: 13 October 2019

Accepted: 15 December 2019

Published: 01 April 2020

\section{KEYWORDS}

Ammonia assimilation; carbonnitrogen interaction; nitrate assimilation; nitrate transporters; nitrogen use efficiency.

\begin{abstract}
The process of nitrate assimilation is a very crucial pathway for the sustainable growth and productivity of higher plants. This process is catalysed by two enzymes, nitrate reductase and nitrite reductase. Both the enzymes differ from each other with respect to their structural organisation, subcellular location, catalytic efficiencies and regulatory mechanisms. Nitrate reductase catalyses the rate limiting step of nitrate assimilation process. The genes and proteins of this enzyme have been isolated and characterised from many higher plants. The additional role of NR in the production of nitric oxide has been also reported in last several years. The reduced ammonium is assimilated into carbon skeleton, $\mathbf{a}-$ ketoglutarate, by the concerted action of glutamine synthetase and glutamate synthase. Glutamine and glutamate are the transportable forms of nitrogen among various tissues and metabolic processes. The rate of nitrate assimilation is regulated by the rate of uptake of nitrate by nitrate transporters, availability of carbon skeleton, accumulation of nitrogenous end products, light and the rate of photosynthesis. The partitioning of metabolites and resources between carbon and nitrogen metabolism is an important factor for the growth and yield of plants. During the last several decades excess use of nitrogen fertiliser has caused environmental pollution. Efforts have been made to increase the nitrogen use efficiency of plants to reduce the cost on fertiliser and nitrate pollution, increase the productivity and protein content of several commonly used crops. This review discusses the process of nitrate assimilation and its interaction with the carbon metabolism.
\end{abstract}

\section{Introduction}

Nitrogen is one of the most essential elements required by all types of organisms because it is a major component of proteins, nucleic acids and other biomolecules. The amount of nitrogen present in plant is 1.5 to $2 \%$ of plant dry matter and $16 \%$ of total protein. Although molecular nitrogen is present in vast amounts in the atmosphere, only a few organisms like bacteria including cyanobacteria can make use of this form of nitrogen to meet their requirement. The major types of nitrogen forms which can be used by plants include ammonia, mineral $\mathrm{N}$ (nitrates and ammonium), oxides of nitrogen (Nox) and amino acids and peptides (1). Mineral nitrogen, ammonium and nitrate are the important sources of nitrogen available in the soils $(2,3)$. Nitrate is the very significant source of nitrogen for most of the plants and algae, as well as many fungi and bacteria. Nitrate assimilation dominates as plants acquire 100 -fold more nitrogen through this process than other nitrogen acquisition processes like nitrogen fixation $(4,5)$.

The assimilatory nitrate reduction pathway is a very important physiological process, as it is one of the major routes by which inorganic nitrogen is assimilated into carbon skeleton in higher plants, algae including cyanobacteria and fungi. Nitrate assimilation is a multistep process which involves nitrate uptake and its reduction to ammonium by two highly regulated enzymes, cytosolic nitrate reductase (NR) and plastidic nitrite reductase (NiR). The reduced ammonium is fixed into the carbon skeleton using 2oxoglutarate provided by TCA cycle and amino acid transamination reactions to form glutamate and glutamine. These two amino acids act as the major donor of nitrogen for the biosynthetic pathways of other nitrogen-containing compounds and secondary

(C) Ali (2020). This is an open-access article distributed under the terms of the Creative Commons Attribution License, which permits unrestricted use, distribution, and reproduction in any medium, provided the original author and source are credited (https://creativecommons.org/licenses/by/4.0/).

To cite this article: Ali A. Nitrate assimilation pathway in higher plants: critical role in nitrogen signalling and utilization Plant Science Today. $2020 ; 7(2): 182-192$. https://doi.org/10.14719/pst.2020.7.2.637 
metabolites. The synthesis of glutamine and glutamate is accomplished by glutamine synthetase and glutamate synthase (GS/GOGAT cycle) (6) (Fig. 1).

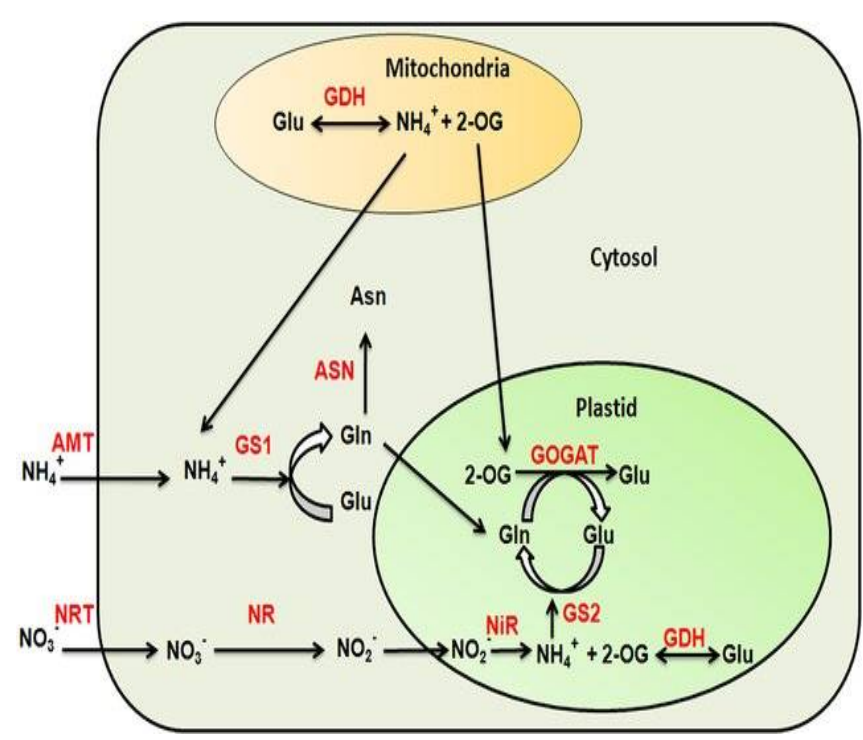

Fig. 1. Nitrate Transport and Assimilation: Nitrate and ammonium are taken up by the root cells by the nitrate (NRT) and ammonium transporters (ART) respectively. Nitrate is converted to nitrite by nitrate reductase (NR) and nitrite is reduced to ammonium by nitrite reductase (NiR) in the plastids. The ammonium is further incorporated into carbon skeleton by glutamine synthetase and glutamate synthase. (Source (7).

\section{NITRATE AND NITRITE TRANSPORT}

\section{Nitrate Transport}

The uptake of nitrate by roots from the soil is the first step in the nitrate assimilation process in plants (reviewed by 8 - 13). The concentration of nitrate varies widely in the agricultural soils and ranges from 1-10 mM. To cope with this large variation in nitrate concentration plants have developed three distinct nitrate uptake systems, two having high affinity and the third having low affinity for nitrate (12). These uptake systems differ from each other with respect to the induction by nitrate and the operational concentration range of nitrate in the soil. The inducible high affinity transport system (iHATS), is strongly induced in the presence of nitrate while the constitutive high affinity transport system (known as cHATS) is constitutively expressed $(14,15)$. The cHATS has high affinity for nitrate [Km values of 6-20 $\mu \mathrm{M}$ compared to 13-79 $\mu \mathrm{m}$ for the iHATS; $(9,12)]$, but the iHATS has a much better capacity for nitrate uptake. The low-affinity transport system (LATS) comes into the picture when the external concentration increases $(>1 \mathrm{mM})(16,17)$. In some plants this system does not require prior exposure to nitrate while in some other the expression increases in the presence of nitrate supply (18).

The genes for nitrate transporters have been cloned and characterised from plants $(8,11,13,19)$. These newly identified genes have been grouped into two different nitrate transporter families: NRT1 and NRT2, according to their sequence analysis $(13,19)$. NRT1 contains low-affinity (mM nitrate) and NRT2 has high-affinity ( $\mu \mathrm{M}$ nitrate) transporters. However one transporter AtNRT1 has been shown to be a dualaffinity transporter (2). There are reports on cloned and functionally characterised low affinity transporter gene, OsNRT1, from rice (20).

\section{Regulation of Nitrate Transport}

The rate of nitrate absorption is the balance between the two opposite fluxes: influx from apoplasm to cytoplasm and efflux in the reverse direction and the transport is a highly regulated process $(11,12,13,19)$. The rate of nitrate uptake into roots is influenced by various environmental and internal signals. The most significant inducer is nitrate itself. A basal level of nitrate uptake having both high and low affinity systems is present in the plants which are either deprived of nitrate or are provided with another source of nitrogen. Upon exposure to nitrate, uptake rate increases. Nitrate uptake decreases when plants are fed high levels of nitrate (feedback inhibition), and ammonium. It has been shown that process of influx is inhibited by ammonium instead of stimulation of efflux and iHATS are more significantly affected than the cHATS or LATS (21). Providing amino acid as the sole nitrogen source for plant growth also exerts a strong inhibition of $\mathrm{NO}_{3}$ uptake (22). Uptake is also affected by circadian rhythms, reduced carbon and shoot nitrogen demand (23).

Primary uptake can also occur in leaves, a route that is important for epiphytes and for incorporation of foliar applications of fertilisers. Once within the plant cell, nitrate may be immediately reduced to ammonium and converted into amino acids. Alternatively the nitrate may be temporarily stored into the plant root system or loaded into the xylem for long distance transport to leaves for subsequent reduction. The vacoular high concentration of nitrate can play role in general osmoticum or become the source of nitrogen during low external supply (24). Reports also suggest the loss of nitrate to the soil by efflux across the plasma membrane (12). The nitrate can be reduced in leaves or roots depending on the external nitrate concentration, developmental age and the type of the plant (25). The major storage organs are root, shoot and leaves.

\section{Nitrite Transport}

The conversion of nitrate to nitrite takes place in cytosol and the further reduction of this nitrite to ammonium requires a chloroplastic enzyme, nitrite reductase, an enzyme dependent on ferredoxin for electrons. Nitrite can be transported in either of the two forms: protonated form $\left(\mathrm{HNO}_{2}\right.$, nitrous acid) or as the nitrite ion. The protonated form diffuses freely across membranes whereas ionic form is probably transported by an active transport system. There are reports that suggest both the mechanisms. The presence of saturable nitrite transporters in the chloroplast membrane, which is sensitive to protein modifiers (26). While other authors have suggested that a proton-linked transport is involved in the transport of nitrite from cytosol to chloroplast. The requirement of an active proton transport for movement of nitrate across the chloroplast envelope is probably met by the presence of an $\mathrm{H}^{+}$-ATPase (27). A new nitrite transporter has been identified, CsNitr1-L, a member of the proton-dependent oligopeptide transporter (POT) family (28). 


\section{ENZYMES OF NITRATE ASSIMILATION}

Once the nitrate is taken up inside the cells, it is converted to ammonium (reduced nitrogen). NAD(P)H:NR nitrate reductase (NR), a molybdenum cofactor (MoCo) cytosolic enzyme, catalyses the first and the rate limiting step of conversion of nitrate to nitrite. This enzyme is highly regulated at all levels of gene expression by several factors. The newly synthesised nitrite is transported to chloroplast where it is immediately converted to ammonia by nitrite reductase (NiR). Ammonia is subsequently fixed into organic acids by the combined action of glutamine synthetase (GS) and glutamate synthase (GOGAT).

\section{Nitrate Reductase}

\section{Isoforms}

Eukaryotic assimilatory nitrate reductase (NR) catalyses the reaction

$$
\mathrm{NO}_{3}{ }^{-}+\mathrm{NAD}(\mathrm{P}) \mathrm{H}+\mathrm{H}^{+} \rightarrow \mathrm{NO}_{2}^{-}+\mathrm{NAD}(\mathrm{P})^{+}+\mathrm{H}_{2} \mathrm{O}
$$

Hence, the conversion of nitrate to nitrite is an irreversible reaction and controlled step of nitrate acquisition in plants, fungi and algal species (29). Different forms of NR have been suggested on the basis of the electron donor they use: an NADHspecific form (EC 1.7.1.1; formerly EC 1.6.6.1) in higher plants and algae; an NAD(P)H-bispecific form (EC 1.7.1.2; formerly EC 1.6.6.2) in higher plants, algae and fungi. A bispecific form only has been reported from birch (30). Monospecific NADPH:NR (EC 1.7.1.3; formerly EC 1.6.6.3) is present in mosses and fungi but is absent from higher plants (31). The NADH specific form can be converted to a NADPH (bi) specific form by making only small structural changes in nitrate reductase. For example, a single amino acid change in birch led to shift in the specificity from a bispecific to a NADH specific enzyme (32). The reason behind possessing nitrate reductase with varied specificities for electron donor is not clear yet. While in root cells NR can utilise both $\mathrm{NADH}$ and NADPH as reductants, the NADH requiring form is known to be present only in leaves.

\section{Subunits}

In higher plants NR is a homodimer made up of two identical subunits of about $110 \mathrm{kDa}(\sim 900$ amino acids). Each subunit contains one equivalent of FAD, heme-Fe and Mo-molybdopterin (Mo-MPT). Dimerisation is required for the activity, and the native NR is a homodimer which can further dimerise to a tetramer. In microorganisms, tetramers of about $500 \mathrm{kDa}$ may also occur. The conversion of nitrate to nitrite is driven by an internal electron chain (Fig. 2) (33).

The 3-D structure of NR reveals five structurally distinct domains: (i) Mo-MPT domain, (ii) dimer interface domain, (iii) cytochrome b (Cb) domain, (iv) FAD binding domain and (v) NAD(P)H binding domain. Cytochrome $\mathrm{b}$ reductase fragment $(\mathrm{CbR})$ is formed as a result of combination of FAD and NADH domains. The combination of FAD and NADH domains leads to the formation of cytochrome $b$ reductase fragment (CbR) which further combines with $\mathrm{Cb}$ domain to form cytochrome $\mathrm{c}$ reductase fragment (CcR).

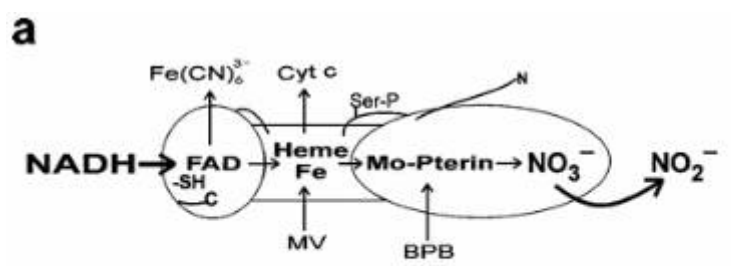

b

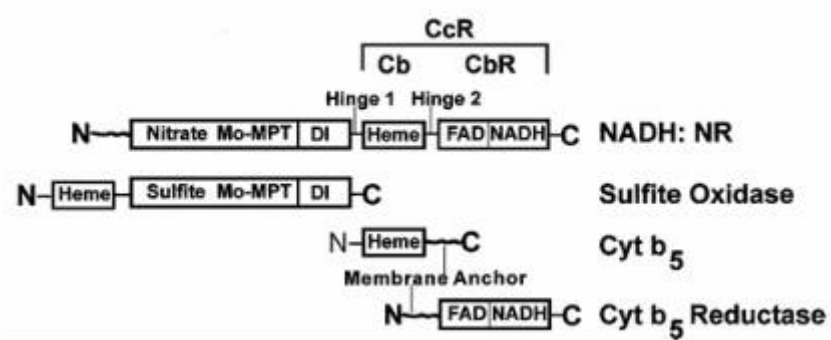

Fig. 2. Models for Nitrate Reductase Structure. (a) Functional model of NR. (b) Sequence model of the enzyme (source: 29).

There are three sequences with no similarities to any other protein and which also vary among the different forms. They are (i) an N-terminal acidic which may be involved in regulations of NRs (ii) a Hinge I region containing a phosphorylated, regulatory serine and a trypsin proteolytic site and (iii) Hinge II, a proteinase site. Thus NR is assembled from subunits that are believed to have evolved separately and which may seem to be related to other protein unit structures. For example $\mathrm{CbR}$ fragment is similar to cytochrome $b_{5}$ reductase whereas the $\mathrm{Cb}$ is closely similar to cytochrome $b_{5}$. It is interesting to note that the Mo-MPT and interface domains of nitrate reductase are identical to sulphite reductase (SOX) which reduces sulphite to sulphate by reduced cytochrome c (29) (Fig. 2).

Each monomeric unit of nitrate reductase has two active sites - one for accepting electron from $\mathrm{NAD}(\mathrm{P}) \mathrm{H}$ and another for conversion of nitrate to nitrite. The enzyme exhibits ping-pong mechanism wherein there is a competition between $\mathrm{NAD}(\mathrm{P})^{+}$and $\mathrm{NAD}(\mathrm{P}) \mathrm{H}$ atone active site and between nitrate and nitrite at the other active site. The domains located between each end of the monomer contain the two active sites: 1) the nitrate-nitrite reduction site between the molybdopterin and dimer interface domains; and 2) the electron-donor active site between the FAD and NADH domains $(29,33,34)$.

The structure of NR consists of three cofactors, namely, FAD, heme and MPT and two metal ions, iron and molybdenum in each monomer. FAD and the two ions can exist in either reduced or oxidised state. Accordingly nitrate reductase can be found in 12-18 possible oxidised or reduced states. The redox potentials indicate a flow of electrons within the NR from electron donor to the active site of the enzyme which actually reduces nitrate (33).

Molybdopterin is a unique cofactor found in some other enzymes in plants, xanthine 
dehydrogenase, aldehyde oxidase and sulphite oxidase (SOX), though the existence of SOX activity in plants has not been proved beyond doubt. These enzymes have been shown to possess a 31-amino acid sequence containing an invariant cysteine residue involved in Mo-MPT binding. This is characteristic of eukaryotic molybdopterin oxidoreductases (35).

Prokaryotic NR also contains molybdenum and a pterin cofactor but differs from eukaryotic molybdopterin in having an extra nucleotide. The bacterial enzymes are membrane bound terminal electron acceptors or soluble enzymes involved in denitrification. A NR activity from Desulfo vibrio, referred to as NAP, and some other prokaryotic NRs have been shown to be unique in possessing an ironsulphur redox centre $\left(\mathrm{Fe}_{4} \mathrm{~S}_{4}\right)$ in the same polypeptide along with the Mo-MPT cofactor. Though no eukaryotic nitrate reductase has been found to have an Fe-S centre in its electron transport chain, the NAP is similar to eukaryotic NR in having an arginine residue involved in nitrate binding (29).

An active site mutant, where the only invariant cysteine replaced by serine, was capable of binding NADH but was unable to transfer electrons from $\mathrm{NADH}$ to FAD. Hence, this cysteine residue (Cys889 in AtNR2) is believed to be the inhibitor-sensitive thiol of NR which is involved in electron transfer but not binding of NADH (29).

\section{Functional Characteristics}

$\mathrm{NR}$ is unusual in being a soluble protein that catalyses an electron transport chain. A very small fraction of total NR activity has been claimed to be membrane associated. The major component, soluble NR has one active site where NADH reduces FAD at the beginning of the ETC and another to reduce nitrate by the molybdopterin. These two are physically separable. Besides nitrate, electrons can also be transferred to other acceptors like ferricyanide and cyt c. Other electron donors like reduced dyes and flavins are possible. Among the dye-dependent activities, bromophenol blue (BPB) and methyl viologen (MV) donate electrons to MoMPT directly during nitrate reduction while $\mathrm{FADH}_{2}$ and $\mathrm{FMNH}_{2}$ require Heme-Fe of the Cyt b. Since BPB and MV dependent activities are higher than NADHNR activity, internal electron transfer appears to be rate limiting (33).

Studies with different recombinant holo-NR forms have revealed two invariant Cys residues. A Cys-191 which is liganded to molybdenum in nitrate reducing active site and a Cys-891 in the NR's second active site which reduces FAD and which is crucial for NADH positioning. Besides, two Arg residues namely, Arg-144 and Arg-196 have been found to be invariant and correspond to Arg residues in SOX. When Arg-144 was mutated to glutamine the mutant enzyme lost Mo-MPT binding activity. Mutations of Arg-196 to glutamine resulted in the enzyme having a higher $\mathrm{k}_{\mathrm{m}}$ for nitrate and resultant lower catalytic efficiency. Studies of recombinant fragments of NR have helped in identifying the residues responsible for electron donor specificity. The importance of the nitrate reductase dimer interface domain was also identified by such studies. It was also observed that the NADPH-NR of Neurospora could be modified into an NADH:NR enzyme by changing a single serine with aspartate in the NADPH domain. Further, kinetic analysis and recombinant expression have also helped in identification of the regulatory ser in Hinge I which gets phosphorylated and in clarifying electron transfer rates (29).

\section{Localisation}

The cytosols of cells of all the vegetative organs of the plant are the major location for the components of nitrate reduction. Depending on the environmental conditions, nitrate reductase is found both in shoots and roots of most species. However, in few species (e.g, cranberry and young chicory) NR is found only in roots, whereas NR is expressed in leaves of some other species (e.g., cocklebur). In $\mathrm{C}_{4}$ plants like maize, $\mathrm{NR}$ is located in mesophyll but not in bundle sheath cells. Although it was reported that the association of NR with chloroplast in spinach leaves through immuno goldlabeling (36), but most of the evidence supports the localization of NR in the cytoplasm of the leaf tissue (37). The presence of nitrate reductase in the cytoplasm of root epidermal and cortical cells as well as in the parenchyma and the pericycle within the vascular tissues has been demonstrated $(29,33)$.

\section{Nitric Oxide (NO) Production by NR}

The fact that nitrate reductase can play an important role in the conversion of nitrite to nitric oxide (NO) has been recognised since long and has been reported by several groups $(2,38,39)$. Since the discovery of $\mathrm{NO}$ as a signalling molecule in the plants it became important to understand the mechanism and the role of NR in the NO production. Investigations are there on the production of NO by purified NR, detached leaves and whole plants (40). It was found that the NR activity used for the NO production from nitrate was insignificant (about 1\%) as compared to the nitrate reduction process. Rapid modulation of NR enzyme and nitrite affected the rate of production of NO by this enzyme. Nitrate $\left(K_{1}\right.$ about $50 \mu \mathrm{M})$ competitively inhibited the NO production from nitrite $\left(K_{\mathrm{m}}-100 \mu \mathrm{M}\right)$, and therefore, NO production by intact tissues was also affected by amount of the nitrate. It has been assumed that both soluble and plasma bound NR may play roles in the generation of NO $(41,42)$. However, the exact role of environmental stress in the regulation of NRdependent nitric oxide production is not clear yet.

\section{Nitrite Reductase}

\section{Structure}

Nitrite reductase (ferredoxin:nitrite oxidoreductase; EC 1.7.7.1) catalyses the six-electron reduction of $\mathrm{NO}_{2}$ to $\mathrm{NH}_{4}^{+}$.

$$
\mathrm{NO}_{2}^{-}+8 \mathrm{H}^{+}+6 \mathrm{e}^{-} \rightarrow \mathrm{NH}_{4}^{+}+2 \mathrm{H}_{2} \mathrm{O}
$$

In contrast to NR which is localised in cytoplasm, nitrite reductase is localised within chloroplasts in leaf and in plastids in root and other non-green tissues (43). However, the presence of an extrachloroplastic NiR has been reported in cotyledons of mustard $(44,45)$. In green leaves, the donor of electron is reduced ferredoxin, generated in the light 
by photosystem I. A ferredoxin-like protein acts as the electron donor in roots where this protein acquires reducing power from NADPH generated by pentose phosphate pathway found in the plastids (46). The addition of nitrate in isolated pea root plastids has been shown to increase the levels of the Fd and NADPH-dependent ferredoxin $\mathrm{NADP}^{+}$oxidoreductase (47).

The nitrite reductase enzymes are monomeric metalloproteins of about 60-64 $\mathrm{kDa}$ containing siroheme prosthetic group, the binding site for nitrite binds and a $4 \mathrm{Fe}-4 \mathrm{~S}$ cluster at its active centre (48). The NiR apoprotein is synthesised in nucleus and the protein is targeted to chloroplast by an $\mathrm{N}$-terminal transit peptide. NiR proteins among plant species show high conservation (75-80 \%). Cyanobacterial $\mathrm{NiR}$ is more closely related to plant than to enterobacterial NiR whereas there is only a very less degree of homology between plant, bacterial and fungal NiR (49). Two isoforms of NiR have been identified in maize and four in $N$. tabacum (50). The enzyme is believed to possess two functional domains and cofactors: an fdx binding domain on the $\mathrm{N}$ terminal and a domain on the C-terminal which has the nitrite binding site, two redox centers, a $4 \mathrm{Fe}-4 \mathrm{~S}$ center and a siroheme. Four cysteines located in two clusters provide a bridge between the domains as well as $\mathrm{S}$ ligands for the $4 \mathrm{Fe}-4 \mathrm{~S}$ cluster. A role for the cysteines in cofactor binding is revealed by mutating the residues next to them to bulky side chains which leads to diminished NiR activity. The siroheme is an iron tetrahydroporphyrin with eight $\mathrm{COOH}-$ containing side chains (51). There are no reports in the literature to indicate that the leaf and root NiRs are different proteins. NiR mutants are difficult to isolate due to the nonviability of the plants on account of toxicity of accumulated nitrite. Reports are on conditional-lethal mutant defective in NiR apoprotein gene, NirI, in barley (52).

Evidence suggests that the $60 \mathrm{kDa} \mathrm{NiR}$ may be a modified form of a larger, native NiR. A putative native NiR of $85 \mathrm{kDa}$ isolated from spinach has a three- to four fold higher specific activity with reduced ferredoxin than with reduced methyl viologen and can be separated into two protein components of 61 and $24 \mathrm{kDa}$. The $61-\mathrm{kDa}$ fragment retains high rates of methyl viologen, but not ferredoxin NiR activity. The $24-\mathrm{kDa}$ fragment has no enzymatic activity, but contains a ferredoxin-binding site (53).

\section{ENZYMES OF AMMONIA ASSIMILATION}

Ammonium, which is highly toxic to plant cells, is rapidly incorporated into carbon skeleton by the action of glutamine synthetase (GS) and glutamate synthase (GOGAT). Together these enzymes constitute the GS/GOGAT cycle, which is the major route of assimilation of ammonia in plants (54). This cycle is also important for the reassimilation of ammonia produced from a variety of other metabolic pathways which include photorespiration, the degradation of amino acids and metabolism of phenylpropanoids.

Once the ammonium is incorporated into glutamate by GS and GOGAT, the nitrogen is transferred to other amino acids by the action of aminotransferases which lead to the formation of aspartate and alanine. Therefore, the GS/GOGAT cycle sits at the interface of the $\mathrm{N}$ and $\mathrm{C}$ metabolism. In higher plants, there are different isoenzymes of GS and GOGAT which are identified by their subcellular location in cytosol and chloroplast. Glutamate dehydrogenase (GDH) is another important enzyme of ammonia assimilation which has the ability to generate glutamate from ammonium. At the same time this enzyme can also deaminate glutamate into ammonium and ketoglutarate. Although this is a widely distributed enzyme in plant cells the exact role of this enzyme in primary ammonia assimilation is still not clear $(55,56)$.

\section{Glutamine Synthetase}

GS (EC 6.3.1.2) catalyses the ATP-dependent conversion of glutamate to glutamine using ammonium as substrate and a divalent cation such as $\mathrm{Mg}^{2+}, \mathrm{Mn}^{2+}$ or $\mathrm{Co}^{2+}$ as a cofactor.

Glutamate $+\mathrm{NH}_{4}+\mathrm{ATP} \rightarrow$ Glutamine $+\mathrm{ADP}+\mathrm{Pi}+\mathrm{H}_{2} \mathrm{O}$

Higher plant GS protein is composed of eight identical or almost identical subunits and has a molecular mass of $\sim 320-380 \mathrm{kDa}$ (57). These subunits are encoded by a small gene family. There are two isoforms of GS: GS1 is primarily located in the cytosol of leaves and nonphotosynthetic tissues and GS2 is found in the chloroplasts, the plastids of roots or etiolated plants (58).

A single nuclear gene codes for the GS2 in most of the plants while GS1 is encoded by small family of nuclear genes (2-6 genes per haploid genome). The stages of development and external stimuli are the key factors responsible for the differential expression of GS1 genes (54). The subunit assembly into homooctameric or heterooctameric form is regulated by a different set of genes (59). These isoforms assimilate ammonium derived by different physiological processes. In roots, GS1 assimilates ammonium derived from the soil and in cotyledons it reassimilates ammonium released by the breakdown of nitrogenous resources during germination. The chloroplast form, GS2, appears to play important role in the primary assimilation of the ammonia reduced from nitrate in the chloroplast and/or reassimilation of photorespiratory ammonium (60). In maize the GS2 is localised in both the mesophyll and bundle sheath cells (54). Cytosolic GS has been reported to be localised in vascular bundle of leaf tissues in rice where it plays a role in exporting nitrogen to sink tissues (61). The primary function of the GS in the root nodules is the quick acquisition of ammonium released into the plant cytosol by the $\mathrm{N}_{2}$-fixing bacteroides. Different environmental conditions and growing season affect the cytosolic and chloroplastic activities.

\section{Glutamate Synthase}

Glutamate synthase (glutamine:oxoglutarate aminotransferase; GOGAT) catalyses the synthesis of two molecules of glutamate from glutamine with ketoglutarate. One molecule of glutamate becomes a substrate for glutamine synthetase and the other is 
used as nitrogen carrier to other tissues or donor for other metabolic processes

$$
\begin{aligned}
& \text { Glutamine }+2-\mathrm{OG}+2 \text { ferredoxin }_{\text {reduced }} \rightarrow 2 \text { glutamate }+ \\
& 2 \text { ferredoxin } \\
& \text { oxidised }
\end{aligned}
$$

There are two isoforms of glutamate synthase depending on the electron donor. Fd GOGAT (EC 1.4.7.1) accepts electron from reduced ferredoxin $\left(\mathrm{Fd}_{\mathrm{red}}\right)$ whereas NADH GOGAT (EC 1.4.1.14) receives electrons from NADH. These enzymes are Fe-S flavoenzymes differing from each other with respect to physicochemical, immunological and regulatory properties and genes encoding them $(54,62,63)$.

The Fd-GOGAT is primarily found in chloroplasts and is involved in the assimilation of ammonia derived from the nitrate assimilation and photorespiration (64). There are reports on the occurrence of this enzyme in the mesophyll cells of rice (65). A single gene codes for the Fd-GOGAT in most of the plants with an exception in Arabidopsis where it is encoded by two genes (66). Although this enzyme is mostly a monomeric one (145-165 $\mathrm{kDa})$, the enzyme present in rice is made up of two subunits of $115 \mathrm{kDa}$ and contains one FMN and one [3Fe-4S] cluster per molecule (67). Light regulates the transcription of Fd-GOGAT gene in leaves leading to an increase in the translational product as well as enzyme activity (56). The dependence on nitrogen sources for transcription and protein activity of the Fd-GOGAT varies from species to species; in some species presence of nitrogen is required for the enzyme activity (68) and in some other species nitrogen does not play any role (69).

NADH-GOGAT (EC 1.4.1.14) is a monomeric enzyme with a molecular mass of 190-240 kDa in land plants. It occurs in the vascular bundles of developing leaf blades. The NADH-GOGAT is less active than the Fd-GOGAT in green leaves (70) but activity and proteins are reported at higher levels in the non-green and developing leaf blades of rice (71). Another isoform of glutamate synthase, NADPHspecific GOGAT (EC 1.4.1.13), has been also reported from some plant species; Pisum arvense, Lycopersicon esculentum and Bryopsis maxima $(72,73)$.

\section{CARBON-NITROGEN INTERACTION}

Plant growth and biomass accumulation are determined largely by the availability, absorption and assimilation of carbon and nitrogen from the environment and carbon release in respiration. Photosynthesis is the main source of energy and carbon skeletons for either carbohydrate or amino acid biosynthesis (74). Carbon and nitrogen metabolites not only serve as the driving forces for growth but are also involved in the transcriptional regulation of enzymes involved in photosynthesis, carbohydrate synthesis and nitrogen assimilation. Growth is modulated so that formation of new plant material closely matches the rate at which carbon and nitrogen are taken into the plant (75).

Much research has also focused on C-N interactions to improve the metabolic capacity of the plant in order to maximise biomass production and $\mathrm{N}$ fertiliser usage, overuse of which has led to the pollution of aquatic environment. The responses of photosynthesis and C metabolism in N-limited plants have been studied especially in order to understand the mechanism by which plants adapt to changes in $\mathrm{N}$ supply. The pathway of $\mathrm{N}$ assimilation responds to changes in the rate of photosynthesis. Similarly, C assimilation pathway and $\mathrm{C}$ partitioning also respond to fluctuations in the supply of inorganic nitrogen (74).

The interaction of nitrogen assimilation with carbon metabolism is complex. Nitrogen assimilation affects the primary carbon metabolism because a large amount of nitrogen is utilised in the proteins and chlorophyll of the photosynthetic apparatus (76). This makes $\mathrm{N}$ availability as the major factor affecting both photosynthetic capacity and crop yield. Conversely, nitrogen assimilation depends on carbon metabolism for (i) the electron donors which are required for conversion of nitrate to ammonium (77), (ii) ketoglutarate as the carbon skeleton for ammonia assimilation by GS/GOGAT pathway, (iii) malate as a counter anion to prevent alkalinisation, (iv) carbon precursors for other amino acid pathways and (v) energy in the form of ATP for nitrate transport into the cell and formation of glutamine, the step catalysed by glutamine synthetase in GS/GOGAT cycle (78). These interactions lead to the partitioning of photosynthetic products between carbohydrate synthesis (between starch and sucrose) and the synthesis of amino acids. The partitioning must be controlled in a flexible manner due to the variability in the external $\mathrm{N}$ availability and internal $\mathrm{N}$ demand (79). This regulation occurs at both transcriptional and post-translational level (80).

Plants differ from each other with respect to the relationships between carbon and nitrogen assimilations which are dependent on various factors. These factors include life cycle and longevity, proportion of $\mathrm{N}$ assimilated in roots and leaves as well as the habitat of the plant which determines the type of nitrogen sources available (79).

There is a 2.5 times more electron requirement for the assimilation of nitrate as compared to the carbon fixation. Although the rate of nitrate assimilation in leaf is very low as compared to carbon metabolism, it utilizes the major amount of photosynthetic resources and energy (81). This is evident from the fact that light is the major stimulator of the process of nitrate assimilation (82, 83).

\section{Reductant Supply}

Leaves are the major site for the photosynthetic activity in higher plants and in most cases this activity is light dependent except in a few specialised plant groups, e.g. CAM plants. On the other hand, a significant amount of nitrogen can be reduced in the absence of light in leaves as well as in the nonphotosynthetic tissues such as roots. In terms of reductant, this reductive assimilation of nitrate requires ten electrons. This reductant is supplied by the photosynthesis, directly through ferredoxin and indirectly through the operation of redox shuttles, or 
via the metabolism of fixed carbon. In leaves, ferredoxin is the major source of electrons for the activities of nitrite reductase and glutamate synthase. Therefore, photosynthesis is the major source of reductant for nitrite and ammonia assimilation into organic acids. Although nitrate assimilation can occur in etiolated leaves containing sufficient carbohydrates, rates are about 2- to 5- fold faster in the light $(82,83)$. Glycolysis and oxidative pentose phosphate pathway (OPPP) are the processes supposed to be involved in supplying reductants in the dark. NADPH, generated by the hexose monophosphate pathway, has been considered to play a significant role in nitrite assimilation in roots, where specific forms of ferredoxin and Fd-NADP reductase may favour transfer of electrons from NADPH to ferredoxin (84). Nitrate reductase being a cytosolic enzyme is dependent on NADH which is generated during the oxidation of carbon.

The amount of photosynthetic electron flow linked to nitrogen assimilation in leaves depends largely on the nitrogen status of the plant. For example, approximately $10 \%$ of the photosynthetic electron was diverted to nitrate assimilation under optimal supplication of nitrogen in barley, pea and tobacco. On the other hand, only about $1 \%$ electron is consumed for nitrate assimilation in $\mathrm{N}$-deprived tobacco (85). When tobacco leaves were fed with nitrate and sucrose, which yielded higher rates of nitrate assimilation as compared to just nitrate fed leaves, the proportion of electron flow for nitrate assimilation increased upto $25 \%$ (86). In higher plants, there is little evidence to suggest that nitrogen assimilation and carbon metabolism compete for photosynthetic electron flow and available resources. Rather, continuous reciprocal coordination at the molecular and metabolic levels in response to environmental stimuli prevents competition and allows adaptive responses to supply and demand. For instance, nitrogen starved algal cells bring about an inhibition of $\mathrm{CO}_{2}$ fixation when they are resupplied with nitrogen. This may indicate rerouting of carbon from the $\mathrm{C}_{3}$ cycle to respiratory pathways and/or utilisation of electrons by $\mathrm{N}$ assimilation.

\section{Supply of Carbon Skeleton for Amino Acid Synthesis}

The biosynthesis of amino acids from reduced nitrogen utilises the major amount of carbon fixed in the chloroplasts. It has been reported that a decrease in the rate of nitrogen metabolism leads to an increase in the accumulation of storage carbohydrates which ultimately reduces the efficiency of photosynthesis (74). Anapleurotic $\mathrm{CO}_{2}$ fixation replaces the TCA cycle intermediates which are consumed during activation of nitrogen assimilation.

In plants and algae, amino acid biosynthesis uses carbon generated during recent photosynthesis if stored carbohydrates are not available $(82,87)$. In fact, $\mathrm{CO}_{2}$ fixation is suppressed in some cells during nitrogen assimilation. There have been a few reports on this drop in $\mathrm{CO}_{2}$ fixation in plants as compared to algae where a limitation of ribulose 1,5-bisphosphate carboxylase (Rubisco) by ribulose 1,5-bisphosphate
(RuBP) has been suggested as the cause for the drop in $\mathrm{CO}_{2}$ fixation (88). The capacity for photosynthesis and the availability of carbohydrates are two factors which decide the source of carbon for amino acid biosynthesis (88). The partitioning of photosynthate to starch decreased with an increase in nitrogen supply in soybean plants (90).

In the dark, stored photosynthates are the source of carbon for nitrogen assimilation (91). The rate of nitrogen assimilation is significantly increased when exogenous carbon is provided to the leaves and roots in the dark (82). The light-dependent fluctuation in the amount of carbohydrate can be accounted for diurnal regulation of nitrogen assimilation in all types of tissues (92). The fact that anapleurotic carbon is required to replace the TCA cycle intermediates consumed in amino acid biosynthesis has been shown by studies on $\mathrm{CO}_{2}$ fixation in dark. The onset of nitrogen assimilation leads to a significant induction of dark $\mathrm{CO}_{2}$ fixation (93). The rates of nitrogen assimilation and anapleurotic carbon fixation are dependent on each other $(93,94)$.

The developmental stage, nitrogen accessibility and the type of the metabolites are the major determinants for the proportion of the fixed carbon required by $\mathrm{N}$ assimilation in plants (81). The most important carbon acceptor of assimilated nitrogen is ketoglutarate. Reports are on the increase in the rate of utilisation of ketoglutarate by GOGAT activity during the photorespiratory $\mathrm{N}$ cycle in the leaves of C3 plants (95). However, there is no net intake of C skeletons in photorespiratory utilisation of ketoglutarate unlike nitrogen assimilation. One molecule of ketoglutarate is utilised for each molecule of ammonium to form glutamate.

\section{NITROGEN USE EFFICIENCY (NUE)}

The availability of nitrogen is the one of the major nutrient requirement and a limiting factor affecting the growth and development of plants (96). The application of additional nitrogen on plants has a significant effect on the crop yield. However, systematic and planned application of nitrogen fertiliser is becoming an important strategy to enhance the crop production. For this reason, the cultivars of many crops in use have been selected on the basis of their capacity to utilise additionally supplied nitrogen (97). But excessive use of fertilisers has led to a range of environmental issues, especially eutrophication of fresh waters (98). Therefore, there has been an increasing demand to decrease the utilisation of $\mathrm{N}$ fertiliser and new plant varieties are being explored for their greater $\mathrm{N}$ use efficiency (NUE). NUE, therefore, can be used as an expression to explain the effectiveness with which plants use nitrogen for their growth and development.

Nitrogen use efficiency is defined as the ratio of nitrogen applied and used by the plants with a significant increase in the biomass. An increased NUE can lead to a decrease demand for $\mathrm{N}$ fertiliser without compromising with the crop yield. The other challenges which affect the crop yield are removal of $\mathrm{N}$ with the harvested plants and fertiliser run-off. Therefore, it becomes important to maintain the amount of $\mathrm{N}$ in the soil for most of the crops being 
non-nitrogen fixers. Accordingly attempts are being made to manipulate the inherent efficiency of the plant to utilise available nitrogen for increased crop productivity at the biological level. This includes nitrogen acquisition and assimilation, relocation within the cell and balance between storage and current use (2).

In the case of cereal crops like rice, NUE is important in terms of both grain yield as well as grain-protein yield, since there is a high demand for improving protein content in food grains to alleviate protein malnutrition in developing countries like India. In the last decade several attempts were made to increase NUE by selectively altering the expression of some of the proteins and enzymes of nitrate acquisition and reduction in transgenic plants. But these experiments have not yielded expected results demonstrating that the earlier notion of single-point rate-limiting regulation is too simple an approach to tackle these problems. Therefore, an enhanced understanding of the regulatory mechanisms of $\mathrm{N}$ metabolism and the factors that regulate the $\mathrm{N}$ and $\mathrm{C}$ traffic is required to find the most appropriate site(s) for future research.

\section{FUTURE PERSPECTIVE}

The process of nitrate assimilation is dependent on carbon fixation for energy and other purposes. The atmospheric carbon dioxide is the major source of carbon skeletons in plants. In last few decades, the concentration of carbon dioxide has increased and there are reports which suggest that the capacity to assimilate nitrate will decrease in high $\mathrm{CO}_{2}$ level (99). Laboratory observations reveal the mechanism by which plants adapt to such situation for optimizing their growth and development. Nitrogen pollution has become another challenge for the researchers and agronomists. Optimizing the use of mixed nitrogen regimes (ammonia and nitrate) can be helpful in solving some of the problems associated with excess usage of nitrogen fertilizers (100).

\section{Conclusion}

Nitrate assimilation pathway is a complex and regulatory process. The enzymes of this process are regulated by various endogenous and exogenous factors like nitrate, ammonia, light and hormones. Nitrate and light are the major signals for this pathway. Ammonia is also assimilated and reassimilated by another set of enzymes. A coordinated regulation of nitrogen and carbon metabolism is essential for the plant growth and is maintained by stringent signalling pathways like protein kinases/phosphatases, calcium, inositol triphosphates etc. However, the exact mechanisms by which the metabolites and reductants are partitioned between the two major primary pathways are still not very clear. Last few years, there has been a great concern about the nitrate pollution because of the excessive use of nitrogen fertilizers. Plants differ from each other with respect to their nitrogen use efficiency. An understanding about the NUE will lead to the proper utilization of fertilisers which in turn will reduce the cost and nitrate pollution.

\section{Competing Interests}

The author declares that there are no competing interests.

\section{References}

1. Wang LX, Macko SA. Constrained preferences in nitrogen uptake across plant species and environments. Plant Cell Environ. 2011;34:525-34. https://doi.org/10.1111/j.13653040.2010.02260.x

2. Wang Ya-Yun, Cheng Yu-Hsuan, Chen Kuo-En, Tsay Yi-Fang. Nitrate transport, signaling, and use efficiency. Annu Rev Plant Biol. 2018;69:85-122. https://doi.org/10.1146/annurev-arplant042817-040056

3. Qu CP, Xu ZR, Hu YB, Lu Y, Yang CJ, Sun GY, et al. RNA-SEQ Reveals Transcriptional Level Changes of Poplar Roots in Different Forms of Nitrogen Treatments. Front Plant Sci. 2016;7:51. https://doi.org/10.3389/fpls.2016.00051

4. Nasholm T, Keilland K, Ganeteg U. Uptake of uptake or organic nitrogen by plants. New Phytol. 2009;182:31-48. https://doi.org/ 10.1111/j.1469-8137.2008.02751.x

5. Ali A, Sivakami S, Raghuram N. Regulation of activity and transcript levels of NR in Rice (Oryza sativa): Roles of Protein Kinase and G-proteins. Plant Sci. 2007;172:406-13. http://doi.org/10.1016/j.plantsci.2006.10.003

6. Lea PJ, Ireland RJ. Nitrogen metabolism in higher plants. In: Singh, BK, editor. Plant amino acids. biochemistry and biotechnology. New York: Marcel Dekker; 1999. p. 1-47.

7. Goel P, Singh AK. Abiotic stresses down regulate key genes involved in nitrogen uptake and assimilation in Brassica juncea L. PLoSONE. 2015;10:e0143645. https://doi:10.1371/journal.pone.0143645

8. Wang R, Liu D, Crawford NM. The Arabidopsis CHL1 protein plays a major role in high-affinity nitrate uptake. Proc Nat $\begin{array}{lll}\text { Acad } & \text { Sci } & \text { USA. }\end{array}$ https://doi.org/10.1073/pnas.95.25.15134

9. Forde BG. Local and long-range signaling pathways regulating plant responses to nitrate. Annu Rev Plant Biol. 2002;53:203-24 https://doi.org/10.1146/annurev.arplant.53.100301.135256

10. Glass ADM. Nitrate uptake by plant roots. Botany. 2009;87:65967. https://doi.org/10.1139/B09-014

11. Galvan A, Fernandez E. Eukaryotic nitrate and nitrite transporters. Cell Mol Life Sci. 2001;58:225-33. https://doi.org/10.1007/PL00000850

12. Kiba T, Krapp A. Plant nitrogen acquisition under low availability: Regulation of uptake and root architecture. Plant Cell Physiol. https://doi.org/10.1093/pcp/pcw052

13. Crawford NM, Glass ADM. Molecular and physiological aspects of nitrate uptake in plants. Trends Plant Sci. 1998;3:389-95. http://doi.org/10.1016/S1360-1385(98)01311-9

14. Aslam M, Travis R, Huffaker R. Comparative kinetics and reciprocal inhibition of nitrate and nitrite uptake in roots of uninduced and induced barley (Hordeum vulgare L.) Seedlings. Plant Physiol. 1992;99:1124-33. https://doi.org/10.1104/pp.99.3.1124

15. Glass ADM, Shaff JE, Kochian LV. Studies of the uptake of nitrate in barley. IV. Electrophysiology. Plant Physiol. 1992; 99:456-63. http://doi.org/ 10.1104/pp.99.2.456

16. Siddiqi MY, Glass ADM, Ruth TJ, Rufty TW Jr. Studies of the uptake of nitrate in barley. Plant Physiol. 1990;93:1426-32. https://doi.org/10.1104/pp.93.4.1426

17. Chrispeels MJ, Crawford NM, Schroeder JI. Proteins for transport of water and mineral nutrients across the membranes of plant cells. Plant Cell. 1999;11(4):661-76. http://doi.org/10.1105/tpc.11.4.661 
18. Kronzucker $\mathrm{HJ}$, Siddiqi MY, Glass ADM. Kinetics of $\mathrm{NO}_{3}{ }^{-}$influx in spruce. Plant Physiol. 1995;109:319-26. https://doi.org/10.1104/pp.109.1.319

19. Forde BG. Nitrate transporters in plants: structure, function and regulation. Biochim Biophys Acta. 2000;1465:219-35. https://doi.org/10.1016/S0005-2736(00)00140-1

20. Lin C-M, Koh S, Stacey G, Yu SM, Lin TY, Tsay YF. Cloning and functional characterization of a constitutively expressed nitrate transporter gene, osnrt1, from Rice. Plant Physiol. 2000;122:379-88. https://doi.org/10.1104/pp.122.2.379

21. Kronzucker HJ, Glass ADM, Siddiqi MY. Inhibition of nitrate uptake by ammonium in barley. Analysis of component fluxes. Plant Physiol.

https://doi.org/10.1104/pp.120.1.283

22. Muller $\mathrm{B}$, Touraine $\mathrm{B}$. Inhibition of $\mathrm{NO}_{3}$ uptake by various phloem-translocated amino acids in soybean seedlings. J Exp Bot. 1992;43:617-23. http://doi.org/10.1093/jxb/43.5.617

23. Crawford NM, Forde BG. Molecular and developmental biology of inorganic nitrogen nutrition. Arabidopsis Book. 2002;1:e0011. http://doi.org/10.1199/tab.0011

24. derLeij M, Smith SJ, Miller AJ. Remobilization of vacuolar stored nitrate in barley root cells. Planta. 1998;205:64-72. https://doi.org/10.1007/s004250050297

25. Faure JD, Meyer C, Caboche M. Nitrate assimilation: nitrate and nitrite reductases. In: Morot-Gaudry JF, editor. Nitrogen assimilation by plants. Enfield: Science Publishers Inc; 2001. p. $33-52$.

26. Brunswick P, Cresswell CF. Nitrite uptake into intact pea chloroplasts: II. Influence of electron transport regulators, uncouplers, ATPase and anion uptake inhibitors and protein binding reagents. Plant Physiol. 1988;86:384-89. https://doi.org/ 10.1104/pp.86.2.384

27. Shingles R, Roh MH, McCarty RE. Nitrite transport in chloroplast inner envelope vesicles. I. Direct measurement of proton-linked transport. Plant Physiol. 1996;112:1375-81. https://doi.org/10.1104/pp.112.3.1375

28. Sugiura M, Georgescu MN, Takahashi M. A nitrite transporter associated with nitrite uptake by higher plant chloroplasts. Plant Cell Physiol. 2007;48:1022-35. https://doi.org/10.1093/pcp/ pcm073

29. Campbell WH. Nitrate reductase, structure, function and regulation: Bridging the gap between biochemistry and physiology. Annu Rev Plant Physiol Plant Mol Biol. 1999;50:277-303.

https://doi.org/10.1146/annurev.arplant.50.1.277

30. Friemann A, Brinkmann K, Hachtel W. Sequence of a cdna encoding bi-specific NAD(P)H-nitrate reductase from the tree Betula pendula and identification of conserved protein regions. Mol Gen Genomics. 1991;227:97-105. http://doi..org/10.1007/bf00260713

31. Zhou J, Kleinhofs A. Molecular evolution of nitrate reductase genes. J Mol Evol. 1996;42:432-42. https://doi.org/10.1007/BF02498637

32. Schondorf $\mathrm{T}$, Hachtel $\mathrm{W}$. The choice of reducing substrate is altered by replacement of an alanine by proline in the FAD domain of a bispecific NADH(P)H-nitrate reductase from birch Plant Physiol. 1995;108:203-10. https://doi.org/10.1104/pp.108.1.203

33. Campbell WH. Molecular control of nitrate reductase and other enzymes involved in nitrate assimilation. In: Foyer $\mathrm{CH}$ Noctor G, editors. Photosynthetic nitrogen assimilation and associated carbon and respiratory metabolism. Dordecht Kluwer Academic Publishers; 2002. p. 35-48. https://doi.org/10.1007/0-306-48138-3_3

34. Campbell WH. Nitrate reductase biochemistry comes of age. Plant Physiol. https://doi.org/10.1104/pp.111.2.355

35. Schwarz G, Mendel RR. Molybdenum cofactor biosynthesis and molybdenum enzymes. Annu Rev Plant Biol. 2006;57:623-47. https://doi.org/10.1146/annurev.arplant.57.032905.105437
36. Kamachi K, Amemiya Y, Ogura N, Nakagawa H. Immuno-gold localization of nitrate reductase in spinach (Spinacea oleracea) leaves. Plant Cell Physiol. 1987;28:333-38. https://doi.org/10.1093/oxfordjournals.pcp.a077300

37. Solomonson LP, Barber MJ. Assimilatory nitrate reductase: functional properties and regulation. Annu Rev Plant Physiol Plant Mol Biol $\quad 1990 ; 41: 225-53$. https://doi.org/10.1146/annurev.pp.41.060190.001301

38. Yamasaki H, Sakihama Y. Simultaneous production of nitric oxide and peroxynitrite by nitrate reductase: in vitro evidence for the NR-dependent formation of active nitrogen species. FEBS Lett. 2000;468:89-92. http://doi.org/10.1016/s00145793(00)01203-5

39. Chamizo-Ampudia A, Sanz-Luque E, Llamas A, Galvan A Fernandez E. Nitrate Reductase Regulates Plant Nitric Oxide Homeostasis. Trends Plant Sci. 2017;22:163-74. DOI:10.1016/j.tplants.2016.12.001

40. Rockel P, Strube F, Rockel A, Wildt J, Kaiser WM. Regulation of nitric oxide (NO) production by plant nitrate reductase in vivo and in vitro. J Exp Bot. 2002;53:103-10. https://doi.org/10.1093/jexbot/53.366.103

41. Stöhr C, Strube P, Marx G, Ullrich, WR, Rockel P. A plasmamembrane-bound enzyme of tobacco or roots catalyses the formation of nitric oxide from nitrite. Planta. 2001;212:835-41. https://doi.org/10.1007/s004250000447

42. Prochazkova D, Haisel D, Pavlikova D. Nitric oxide biosynthesis in plants-the short overview. Plant Soil Environ. 2014;60:129-34. https://doi.org/10.17221/901/2013-PSE

43. Oaks A, Hirel B. Nitrogen Metabolism in roots. Annu Rev Plant Physiol. https://doi.org/10.1146/annurev.pp.36.060185.002021

44. Schuster C, Mohr H. Photooxidative damage to plastids affects the abundance of nitrate reductase mRNA in mustard $\begin{array}{lll}\text { cotyledons. } & \text { Planta. } & \text { 1990;181:125-28. }\end{array}$ https://doi.org/10.1007/BF00202334

45. Schuster C, Mohr H. Appearance of nitrite reductase mRNA in mustard seedling cotyledons is regulated by phytochrome. Planta. 1990;181:327-34. https://doi.org/10.1007/BF00195884

46. Yoneyama T, Suzuki A. Exploration of nitrate-to-glutamate assimilation in non-photosynthetic roots of higher plants by studies of (15)N-tracing, enzymes involved, reductant supply, and nitrate signaling: A review and synthesis. Plant Physiol Biochem.

https://doi.org/10.1016/j.plaphy.2018.12.011

47. Bowsher CG, Hucklesby DP, Emes MJ. Induction of ferredoxin$\mathrm{NADP}^{+}$oxidoreductase and ferredoxin synthesis in pea root plastids during nitrate assimilation. Plant J. 1993;3:463-67. https://doi.org/10.1111/j.1365-313X.1993.tb00166.x

48. Hase T, Schürmann P, Knaff DB. The interaction of ferredoxin with ferredoxin-dependent enzymes. In: Golbeck J, editor. Photosystem 1. Dordrecht, The Netherlands: Springer; 2006. p. 477-98. https://doi.org/10.1007/978-1-4020-4256-0_28

49. Fariduddin Q, Varshney $\mathrm{P}$, Ali A. Perspective of nitrate assimilation and bioremediation in Spirulina platensis (a nonnitrogen fixing cyanobacterium): An overview. J Env Biol. 2018;39:547-57. http://doi.org/10.22438/jeb/39/5/MS-172

50. Sivasankar S, Rothstein S, Oaks A. Regulation of the accumulation and reduction of nitrate by nitrogen and carbon metabolites in maize seedlings. Plant Physiol. 1997;114:583-89. https://doi.org/10.1104/pp.114.2.583.

51. Maia LB, Moura JGJ. How biology handles nitrite. Chem. Rev 2014;114:5273-357._https://doi.org/10.1021/cr400518y

52. Duncanson E, Gilkes AF, Kirk DW, Sheman A, Wray JL. Niri, a conditional-lethal mutant in barley causing a defect in nitrite reduction. Mol Gen Genet. 1993;236:275-82 https://doi.org/10.1007/BF00277123

53. Kishorekumar R, Bulle M, Wany A, Gupta KJ. An Overview of Important Enzymes Involved in Nitrogen Assimilation of Plants. In: Gupta K. Editor. Nitrogen Metabolism in Plants. Methods in Molecular Biology, 2020; vol 2057. New York Humana. https://doi.org/10.1007/978-1-4939-9790-9_1 
54. Coruzzi GM. Primary N-assimilation into Amino Acids in Arabidopsis. The Arabidopsis Book. 2003;2:e0010. http://doi.org10.1199/tab.0010

55. Melo-Oliveira R, Cinha-Oliveira I, Coruzzi GM. Arabidopsis mutant analysis and gene regulation define a non-redundant role for glutamate dehydrogenase in nitrogen assimilation. Proc Natl Acad Sci USA. 1996;96:4718-23. https://doi.org/10.1073/pnas.93.10.4718

56. Anjana, Umar S, Iqbal M. Nitrate accumulation in plants, factors affecting the process, and human health implications. A review. Agron Sustain Dev. 2007;27:45-57. https://doi.org/10.1051/agro:2006021

57. Secheley KA, Yamata T, Oaks A. Compartmentation of nitrogen assimilation in higher plants. Int Rev Cyt. 1992;134:85-163. https://doi.org/10.1016/S0074-7696(08)62028-8

58. Cren M, Hirel B. Glutamine synthetase in higher plants: Regulation of gene and protein expression from the organ to the cell. Plant Cell Physiol. 1999;40:1187-93. https://doi.org/10.1093/oxfordjournals.pcp.a029506

59. Inokuchi R, Kuma K, Miyata T, Okada M. Nitrogen-assimilating enzymes in land plants and algae: phylogenic and physiological perspectives. Physiol Plant. 2002;116:1-11. https://doi.org/10.1034/j.1399-3054.2002.1160101.x

60. Lam HM, Coschigano KT, Oliveira IC, Melo-Oliveira R, Coruzzi GM. The molecular genetics of nitrogen assimilation into amino acids in higher plants. Annu Rev Plant Physiol Plant Mol Biol. https://doi.org/10.1146/annurev.arplant.47.1.569 1996;47:569-93.

61. Masclaux-Daubresse C, Daniel-Vedele F, Dechorgnat J, Chardon F, Gaufichon L, Suzuki A., Nitrogen uptake, assimilation and remobilization in plants: challenges for sustainable and productive agriculture, Annals Bot. 2010;105:1141-57. https://doi.org/10.1093/aob/mcq028

62. Suzuki A, Knaff DB. Glutamate synthase: structural, mechanistic and regulatory properties, and role in the amino acid metabolism. Photosynth Res. 2005;83:191-217. https://doi.org/10.1007/s11120-004-3478-0

63. Temple SJ, Vance CP, Gantt JS. Glutamate synthase and nitrogen assimilation. Trends Plant Sci. 1998;3:51-56. https://doi.org/10.1016/S1360-1385(97)01159-X

64. Forde B, Lea P. Glutamate in plants: Metabolism, regulation, and signalling. J Exp Bot. 2007; 58:2339-58. https://doi.org/10.1093/jxb/erm121

65. Hayakawa T, Nakamura T, Hattori F, Mae T, Ojima K, Yamaya T. Cellular localization of NADH-dependent glutamate synthase protein in vascular bundles of unexpanded leaf blades and young grains of rice plants. Planta. 1994;193:455-60. https://doi.org/10.1007/BF00201826

66. Coshigano KT, Melo-Oliveira R, Lim J, Coruzzi GM. Arabidopsis gls mutants and distinct Fd-GOGAT genes: implication for photorespiration and primary nitrogen assimilation. Plant Cell. 1998;10:741-52. https://doi.org/10.1105/tpc.10.5.741

67. Hirasawa M, Hurley JK, Salamon Z, Tollin G, Knaff DB. Oxidation-reduction and transient kinetics of ferredoxin dependent glutamate synthase. Arch Biochem Biophys. 1996; 330: 209-15. https://doi.org/10.1006/abbi.1996.0244

68. Sakakibara H, Kawabata S, Hase T, Sugiyama T. Differential effect of nitrate and light on the expression of glutamine synthetase and ferredoxin-dependent glutamate synthase in maize. Plant Cell Physiol. 1992;33:1193-98. https://doi.org/10.1093/oxfordjournals.pcp.a078373

69. Migge A, Carrayol E, Hirel B, Lohmann M, Meya G, Becker TW. Influence of UV-A or UV-B light and of the nitrogen source on the induction of ferredoxin-dependent glutamate synthase in etiolated tomato cotelydons. Plant Physiol Biochem. 1998;36:789-97. https://doi.org/10.1016/S0981-9428(99)80015-1

70. Hecht U, Oelmuller R, Schmidt S, Mohr H. Action of light, nitrate and ammonium on the levels of NADH- and ferredoxindependent glutamate synthase in the cotyledons of mustard seedlings. Planta. https://doi.org/10.1007/BF00402890
71. Yamaya T, Hayakawa T, Tanasawa K, Kamachi K, Mae T, Ojima $\mathrm{K}$. Tissue distribution of glutamate synthase and glutamine synthetase in rice leaves. Occurrence of NADH-dependent glutamate synthase protein and activity in the unexpanded non-green leaf blades. Plant Physiol. 1992;100:1427-32. https:// doi.org/10.1104/pp.100.3.1427

72. Kubik-Dobasz G. The activity of NADH, NADPH and ferredoxindependent glutamate synthase in the plastids and cytosol of Pisum arvense L. root cells. Acta Societatis Botanicorum Poloniae. 1989;58:253-62. https://doi.org/10.5586/asbp.1989.021

73. Rus-Alvarez A, Guerrier G. Proline metabolic pathways in calli from Lycopersicum esculentum and L. Pennellii under salt stress. Biol Plant (Prague). 1994;36:277-84. https://doi.org/10.1007/BF02921101

74. Foyer $\mathrm{CH}$, Ferrario S. Modulation of carbon and nitrogen metabolism in transgenic plants with a view to improved biomass production. Biochem Soc Transac. 1994;22:909-15. https://doi.org/10.1042/bst0220909

75. Oliveira IC, Brenner E, Chiu J, Hsieh M-H, Kouranov A, Lam HM, Shin MJ, Coruzzi G. Metabolite and light regulation of metabolism in plants: lessons from the study of a single biochemical pathway. Braz J Med Biol Res. 2001;34:567-75. http://dx.doi.org/10.1590/S0100-879X2001000500003

76. Kant S, Seneweera S, Rodin J, Materne M, Burch D, Rothstein SJ, Spangenberg G. Improving yield potential in crops under elevated $\mathrm{CO}_{2}$ : integrating the photosynthetic and nitrogen utilization efficiencies. Front Plant Sci. 2012;3:162. https://doi.org/10.3389/fpls.2012.00162

77. Kaiser WM, Kandlbinder A, Stoimenova M, Glaab J. Discrepancy between nitrate reduction rates in intact leaves and nitrate reductase activity in leaf extracts: what limits nitrate reduction in situ? Planta. 2000;210:801-07. https://doi.org/10.1007/s004250050682

78. Xu G, Fan X, Miller AJ. Plant nitrogen assimilation and use efficiency. Annu Rev Plant Biol. 2012;63:153-82. https://doi.org/10.1146/annurev-arplant-042811-105532

79. Foyer C, Ferario-Mery S, Noctor G. Interactions between carbon and nitrogen metabolism. In: Lea PJ, Morot-Gaudry JF, editors. Plant nitrogen. Berlin: Springer Verlag; 2001. p. 23754. https://doi.org/10.1007/978-3-662-04064-5_9

80. Li H, Liang Z, Ding G, Shi L, Xu F, Cai H. A Natural Light/Dark Cycle Regulation of Carbon-Nitrogen Metabolism and Gene Expression in Rice Shoots. Front Plant Sci. 2016;7:1318. https://doi.org/10.3389/fpls.2016.01318

81. Scheible WR, Gonzales-Fontes A, Morcuende R, Lauerer M, Geiger M, Glaab J, Schulze E-D, Stitt M. Tobacco mutants with a decreased number of functional nia-genes compensate by modifying the diurnal regulation transcription, posttranslational modification and turnover of nitrate reductase. Planta. 1997;203:305-19. https://doi.org/10.1007/s004250050196

82. Lewis E, Noctor G, Causton D, Foyer CH. Regulation of assimilate partitioning in leaves. Aust J Plant Physiol. 2000; 27: 507-17. https://doi.org/10.1071/PP99177

83. Aslam M, Huffaker RC, Rains DW, Rao KP. Influence of light and ambient carbon dioxide concentration on nitrate assimilation by intact barley seedlings. Plant Physiol. 1979;63:1205-09. https://doi.org/10.1104/pp.63.6.1205

84. Nunes-Nesi A, Fernie AR, Stitt M. Metabolic andsignaling aspects underpinning the regulation of plant carbon nitrogen interactions. Mol Plant. 2010;3:973-96. https://doi.org/10.1093/ $\mathrm{mp} / \mathrm{ssq} 049$

85. Emes MJ, Neuhaus HE. Metabolism and transport in nonphotosynthetic plastids. J Exp Bot. 1997;48:1995-2005 https://doi.org/10.1093/jxb/48.12.1995

86. Banks FM, Driscoll SP, Parry MAJ, Lawlor DW, Knight JS, Gray IC, et al. Decrease in phosphoribulokinase activity by antisense RNA in transgenic tobacco: relationship between photosynthesis, growth, and allocation at contrasting nitrogen supplies. Plant Physiol. 1999;119:1125-36. https://doi.org/10.1104/pp.119.3.1125

87. Morcuende R, Krapp A, Hurry V, Stitt M. Sucrose feeding leads to increased rates of nitrate assimilation, increased rates of 
oxoglutarate synthesis, and increased synthesis of a wide spectrum of amino acids in tobacco leaves. Planta. 1998;206:394-409. https://doi.org/10.1007/s004250050415

88. Amory AM, Vanlerberghe GC, Turpin DH. Demonstration of both a photosynthetic and nonphotosynthetic $\mathrm{CO}_{2}$ requirement for $\mathrm{NH}_{4}^{+}$assimilation in the green alga Selenastrumminutum. Plant Physiol 1991;95:192-96.

https://doi.org/10.1104/pp.95.1.192

89. Elrifi IR, Holmes JJ, Weger HG, Mayo WP, Turpin DH. Rubp limitation of photosynthetic carbon fixation during $\mathrm{NH}_{3}$ assimilation. Interactions between photosynthesis, respiration, and ammonium assimilation in N-limited green algae. Plant Physiol.

https://doi.org/10.1104/pp.87.2.395 1988;87:395-401.

90. Pace GM, Volk RJ, Jackson WA. Nitrate reduction in response to $\mathrm{CO}_{2}$-1imited photosynthesis. Relationship to carbohydrate supply and nitrate reductase activity in maize seedlings. Plant Physiol. 1990;92:286-92. https://doi.org/10.1104/pp.92.2.286

91. Galangau F, Daniel-VedBle F, Moureaux T, Dorbe MF, Leydecker MT, Caboche M. Expression of leaf nitrate reductase genes from tomato and tobacco in relation to light dark regimes and nitrate supply. Plant Physiol. 1988;88:383-88. https://doi.org/10.1104/pp.88.2.383

92. Stitt M, Krapp A. The interaction between elevated carbon dioxide and nitrogen nutrition: the physiological and molecular background. Plant Cell Environ. 1999;22:583-621. https://doi.org/10.1046/j.1365-3040.1999.00386.x

93. Rufty TW, Mackown CT, Volk RJ. Effects of altered carbohydrate availability on whole-plant assimilation of ${ }^{15} \mathrm{NO}_{3}$. Plant Physiol. 1989;89:457-63. https://doi.org/10.1104/pp.89.2.457
94. Le VQ, Foyer C, Champigny ML. Effect of light and $\mathrm{NO}_{3}{ }^{-}$on wheat leaf phosphoenolpyruvate carboxylase activity. Plant Physiol.

https://doi.org/10.1104/pp.97.4.1476 1991;97):1476-82.

95. Vanlerberghe GC, Schuller KA, Smith RG, Feil R, Plaxton WC Turpin, DH. Relationship between $\mathrm{NH}_{4}^{+}$assimilation rate and in vivo phosphoenolpyruvate carboxylase activity. Plant Physiol. 1990;94:284-290. https://doi.org/10.1104/pp.94.1.284

96. Krapp A. Plant nitrogen assimilation and its regulation: A complex puzzle with missing pieces. Curr Opin Plant Biol 2015;25:115-22. https://doi.org/10.1016/j.pbi.2015.05.010

97. Lammerts van Bueren ET, Struik PC. Diverse concepts of breeding for nitrogen use efficiency. A review. Agron Sustain Dev. 2017;37:50. https://doi.org/10.1007/s13593-017-0457-3

98. Andrews M, Lea PJ, Raven JA, Lindsey K. Can genetic manipulation of plant nitrogen assimilation enzymes result in increased crop yield and greater N-use efficiency? An assessment. Annals App Biol. 2004;145:25-40. https://doi.org/10.1111/j.1744-7348.2004.tb00356.x

99. Hachiya T, Sakakibara H. Interactions between nitrate and ammonium in their uptake, allocation, assimilation, and signaling in plants. J Exp Bot. 2017;68:2501-12, https://doi.org/10.1093/jxb/erw449

100. Britto DT, Kronzucker $\mathrm{HJ} . \mathrm{NH}_{4}{ }^{+}$toxicity in higher plants: a critical review. J Plant Physiol. 2002;159:567-84. https://doi.org/10.1078/0176-1617-0774 